\title{
PENENTUAN MASA SIMPAN KOPI BUBUK DALAM KEMASAN ALUMINIUM LAMINATED POLYETILEN (ALP) DAN POLYETILEN PTALAT (PET)
}

\section{THE DETERMINATION OF SHELF LIFE OF GROUND ROASTED COFFEE IN ALUMINUM LAMINATED POLYETHYLENE (ALP) AND POLY ETHYLENE PHTHALATE (PET) PACKAGING}

\author{
Oktavia Andayani ${ }^{1}$, Sri Agustini ${ }^{2}$ \\ ${ }^{1,2}$ Balai Riset dan Standardisasi Industri Palembang \\ Jalan Kolonel H. Palembang, Sumatera Selatan, Indonesia 30152 \\ Correspondence: No HP +6281532898196, Fax: +62711412482 \\ email address.sragustini@yahoo.com
}

Diterima: 10 Agustus 2019; Direvisi: 11 September - 26 November 2019; Disetujui: 16 Desember 2019

\begin{abstract}
Abstrak
Kopi bubuk merupakan produk industri kecil yang banyak ditemukan di pasar dan dikonsumsi oleh sebagian besar masyarakat. Umumnya kopi bubuk dijual dalam kemasan plastik tanpa disertai dengan informasi masa simpan/masa kedaluarsa. Penelitian ini bertujuan untuk mempelajari perubahan mutu dan masa kopi bubuk dalam kemasan dari sisi kontaminasi mikrobiologi. Penelitian ini disusun menggunakan rancangan acak lengkap yang disusun secara faktorial. Faktor pertama adalah jenis kemasan yang terdiri dari kemasan berbahan ALP dan kemasan berbahan PET. Faktor kedua adalah waktu simpan yang terdiri dari 0,2,4,6, 8,10 dan 12 bulan. Perubahan kontaminasi mikrobiologi dilakukan melalui pengamatan angka lempeng total dan cemaran kapang/khamir menggunakan metode SNI. Hasil pengamatan menunjukkan bahwa terjadi penurunan angka lempeng total dan cemaran kapang/khamir pada kopi bubuk selama penyimpanan. Kemasan berbahan ALP memberikan perlindungan terhadap cemaran mikroba yang lebih baik dibandingkan PET.
\end{abstract}

Kata kunci : ALT, kemasan ALP, kemasan PET, kapang Khamir, kopi bubuk

\begin{abstract}
Ground roasted coffee is a product that found in many markets and consumed by most people. Generally it is sold in plastic packaging without information about the shelf life / expiration. This study aims to study changes in the quality and shelf life of ground roasted coffee in a single service packaging in terms of microbiological contamination. This research was designed by using a completely randomized design arranged factorially. The first factor is the type of packaging materials consisting of ALP and PET-based packaging. The second factor is the storage time consisting of 0,2,4,6, 8, 10 and 12 months. Changes in microbiological contamination are done through observing the total plate counts and mold / yeast contamination using the SNI method. The observations showed that there was a decrease in total plate count and mold / yeast contamination in ground coffee during storage. ALP packaging provides better protection against microbial contamination than of PET.
\end{abstract}

Keywords : TPC, ALP, PET, yeast and mold, ground roasted coffee,

\section{PENDAHULUAN}

Indonesia merupakan produsen kopi keempat setelah Brasil, Vietnam dan Kolombia, dan juga sekaligus konsumen penting komoditas kopi. Sebagai konsumen, Indonesia menempati urutan ketujuh (International Coffee Organization /ICO, 2017). Yulia dan Suhandy (2018) menyatakan bahwa pada tahun 2017 Indonesia menguasai 7,5\% produksi kopi dunia. Asosiasi Eksportir dan Industri Kopi Indonesia (AEKI) menyebutkan pertumbuhan konsumsi kopi nasional meningkat dari 0,8 kilogram per kapita menjadi 1,3 kilogram per kapita. Perkembangan industri kopi dunia juga berimbas pada industri kopi Indonesia.

Salah satu produk olahan kopi yang banyak di temui adalah kopi bubuk. Produksi kopi bubuk di Indonesia saat ini diperkirakan telah mencapai 150.000 ton, sedangkan untuk kopi instant dan turunannya telah mencapai 20.000 ton. Data BPS (Biro Pusat Statistik) mencatat bahwa volume ekspor kopi soluble ratarata dalam 5 tahun terakhir mencapai 
sekitar 15.000 ton per tahun sedangkan ekspor kopi bubuk mencapai 3.000 ton per tahun.

Kopi bubuk merupakan salah satu dari produk yang dikonsumsi secara luas tidak saja oleh konsumen Indonesia tapi juga konsumen dunia. Kopi dinikmati karena memiliki flavor yang unik, dimana kualitas dan keberterimaannya tergantung pada flavor dan aromanya. Kualitas kopi ditentukan oleh tahapan tahapan penyiapannya termasuk penyangraian, penggilingan, pengemasan dan cara penyeduhan. Perubahan kualitas kopi mulai terjadi pada awal proses penyiapan kopi sehingga mengakibatkan kehilangan aroma dan kesegaran flavor (Vila et al., 2005). Perubahan ini dapat dianggap sebagai staling yang didefinisikan sebagai flavor dan aroma manis tapi tidak enak yang disebabkan karena hilangnya berbagai senyawa volatil (Buffo dan Cardelli-Freire, 2004). Selain penurunan senyawa volatil, penurunan mutu juga disebabkan oleh degradasi lipida akibat lipolisis dan oksidasi lipida (Vila et al., 2005) selama masa penyimpanan. Perubahan mutu kopi yang terjadi selama penyimpanan sangat penting karena dapat mempengaruhi penilaian konsumen. Kreuml et al. (2013) menyatakan bahwa selama penyimpanan terjadi transformasi kandungan kimia karena kopi yang telah disangrai sangat rentan terhadap perubahan fisika dan kimia yang dapat mempengaruhi kualitas seduhan kopi.

Salah satu proses yang berpengaruh terhadap mutu produk selama penyimpanan adalah pengemasan. Aluminium laminated polyethylene (ALP) dan Polyethylene terephthalate (PET) merupakan kemasan fleksibel yang sering digunakan di dalam pengemasan kopi. ALP merupakan laminasi film aluminium yang mengikat aluminium foil bersama dengan kertas atau plastik seperti polietilen atau polipropilen untuk meningkatkan sifat penghalang (Marsh dan Bugusu, 2007). Laminasi aluminium ke plastik memungkinkan sealibilitas panas dari bahan kemasan. Ini juga memberikan penghalang yang sangat baik untuk cahaya dan mengurangi permeabilitas oksigen (Abdel-Bary, 2003). Masing-masing komponen aluminium laminasi polietilen dapat didaur ulang. Polietilen tereftalat (PET) adalah jenis poliester yang dibentuk oleh reaksi antara dimetil tereftalat dan etilen glikol (Marsh dan Bugusu, 2007). PET memberikan penghalang yang baik terhadap gas, kelembaban, panas, minyak mineral, pelarut dan asam (Hui, 2006).

Masa simpan suatu produk adalah jarak waktu antara pengemasan sampai mutu produk secara sensorik dan mutu fisika kimia masih memenuhi syarat untuk dikonsumsi atau masih diterima oleh konsumen yang berkaitan dengan keamanan dan kelayakan produk, dan memberikan petunjuk terjadinya perubahan citarasa, penampakan dan kandungan gizi produk tersebut (Cardeli dan Labuza, 2001; Sudibyo et al., 2010). Di pasar dikenal dua jenis kopi bubuk, yaitu kopi bubuk yang dikemas dalam kemasan plastik dengan ukuran ekonomis $(>100 \mathrm{~g})$ dan kopi bubuk kemasan sekali saji (sachet $7 \mathrm{~g}$ ). Umumnya kopi bubuk kemasan ekonomis tidak mencantumkan masa simpan produk, sedangkan kopi kemasan sachet mencantumkan masa simpan 1-2 tahun. Yulia dan Suhandy (2018) menyatakan bahwa masa simpan kopi bubuk yang dikemas di dalam kaleng maupun kemasan fleksibel hanya 1 bulan dan dapat diperpanjang hingga 4-6 bulan dengan menggunakan kemasan vakum. Herawati (2008) menyatakan bahwa penentuan umur simpan dapat dilakukan dengan beberapa cara diantaranya dilakukan dengan cara menyimpan produk sampai produk tersebut rusak sehingga diperoleh umur atau waktu simpannya. Metode ini sangat tepat untuk menentukan umur simpan karena produk benar-benar diketahui kerusakannya. Akan tetapi, metode ini memerlukan waktu yang lama sehingga aplikasinya sulit untuk produk-produk yang memiliki umur simpan sangat panjang.

Penelitian mengenai penentuan masa simpan kopi telah banyak dilakukan, 
diantaranya : Cardeli dan Labuza (2001) mengaplikasikan metode weibull hazards analysis di dalam menentukan masa simpan kopi bubuk dan kopi sangrai. Mc.Gee (2004) merekomendasikan penyimpanan kopi pada suhu ruang atau dibekukan di dalam kontainer dalam bentuk kopi sangrai selama beberapa bulan sebelum menjadi apek. Ross et al. (2006) menemukan bahwa kopi bubuk spesies arabika yang disimpan selama dua minggu memiliki aroma yang lebih keras dan lebih pahit dibandingkan dengan fresh kopi. Sudibyo et al. (2010) melakukan pendugaan umur simpan kopi instan menggunakan metode penyimpanan yang diakselerasi (ASS). Kreum et al. (2013) mengamati penurunan mutu sensoris kopi sangrai yang disimpan di dalam kemasan vakum, Correa et al. (2015) mengamati perubahan bulk density kopi sangrai dan kopi bubuk yang dikemas dalam plastik propilen pada suhu $30^{\circ} \mathrm{C}$ selama 6 bulan. Semua penelitian ini sangat berharga, dan beberapa penelitian telah membahas penyimpanan kopi bubuk pada kondisi yang berbeda, namun belum ada penelitian yang membahas masa simpan kopi pada kondisi dan pengemasan dikaitkan dengan perubahan atribut keamanan khususnya cemaran mikroba. Tujuan dari penelitian ini adalah untuk menentukan masa simpan kopi bubuk yang disimpan pada suhu kamar pada jenis kemasan yang berbeda dari sisi cemaran mikroba.

\section{BAHAN DAN METODE}

\section{Bahan}

Kopi bubuk dan kemasan yang digunakan dalam penelitian ini disediakan oleh PD. Sahang Mas produsen kopi Benua di kota Palembang. Kopi bubuk yang digunakan merupakan kopi blended antara kopi Robusta dan Arabika dengan perbandingan $80: 20 \%$. Jenis kemasan yang digunakan terdiri dari aluminum laminated polyethylene (ALP) yang terbuat dari $12 \mu \mathrm{m}$ polyethylene terephthalate (PET) dan $15 \mu \mathrm{m}$ PE, dilaminasi dengan $7 \mu \mathrm{m}$ aluminum (Al) dan $25 \mu \mathrm{m}$ copolymer polypropylene (CPP). Polyethylene terephthalate (PET) terbuat dari $12 \mu \mathrm{m}$ polyethylene terephthalate (PET), $9 \mu \mathrm{m}$ silicon oxide SiOx, $15 \mu \mathrm{m}$ nylon (NY) dengan $65 \mu \mathrm{m}$ random copolymer polypropylene (RCPP). Kopi bubuk dikemas dalam bentuk sachet untuk setiap jenis kemasan dengan ukuran $5.0 \mathrm{~cm} \times 2.0 \mathrm{~cm}$ dengan berat $7 \mathrm{~g}$. Pengemasan kopi bubuk dilakukan menggunakan mesin pengemas yang dilengkapi dengan nitrogen flushing. Penyimpanan kopi bubuk yang telah dikemas dilakukan dengan cara meletakkan di dalam lemari pada suhu ruang pada waktu tertentu.

\section{Peralatan}

Peralatan untuk pengujian meliputi neraca analitik, oven, incubator, laminar flow, colony counter, mikroskop, dan peralatan gelas yang diperlukan untuk uji mikrobiologi.

\section{Metode}

Rancangan penelitian yang digunakan dalam penelitian ini adalah rancangan acak lengkap (RAL) dengan jenis kemasan sebagai perlakuan, yaitu kemasan ALP dan PET dan waktu penyimpanan. Pengamatan yang dilakukan adalah angka lempeng total (ALT) dan cemaran kapang dan jamur yang dilakukan pada interval 2 bulan yaitu 2, 4, 6,8, 10 dan 12 bulan. Pengujian angka lempeng total (ALT) dan cemaran kapang/jamur menggunakan metode SNI/ AOAC 2009. Setiap perlakuan dilakukan dengan 3 replikasi. Data hasil pengujian dibandingkan dengan standar nasional kopi bubuk SNI 01-3542-2004. Masa simpan kopi bubuk ditentukan berdasarkan kandungan cemaran mikroba yang masih memenuhi persyaratan SNI 01-3542-2004.

\section{HASIL DAN PEMBAHASAN}

Angka lempeng total (ALT) menunjukkan jumlah mikroba dalam suatu 
produk. ALT juga disebut sebagai Aerobic plate count (APC), Standard plate count (SPC), atau Aerobic microbial count (AMC). Secara umum ALT menunjukkan kualitas, masa simpan, kontaminasi dan status higienis pada saat produksi dan tidak terkait langsung dengan keamanan pangan. Standar Nasional Indonesia untuk kopi bubuk mensyaratkan batas maksimum cemaran ALT pada kopi sebesar $1 \times 10^{6}$ koloni/g. Rerata hasil pengujian ALT kopi bubuk untuk masing masing umur penyimpanan dapat dilihat pada Tabel 1.

Tabel 1. Hasil uji ALT dan kapang/khamir kopi bubuk

\begin{tabular}{lllll}
\hline $\begin{array}{l}\text { Masa } \\
\text { Simpan } \\
\text { (Bulan) }\end{array}$ & \multicolumn{2}{c}{ ALT (cfu/g) } & \multicolumn{3}{c}{ Kapang/kamir cfu/g) } \\
\hline 0 & $1,3 \times 10^{3}$ & $1,3 \times 10^{3}$ & $1.5 \times 10^{3}$ & $1.5 \times 10^{3}$ \\
2 & $2,2 \times 10^{3}$ & $2,2 \times 10^{3}$ & $<10$ & $9.7 \times 10^{3}$ \\
4 & $6,8 \times 10^{2}$ & $2,3 \times 10^{3}$ & $<10$ & $9.7 \times 10^{2}$ \\
6 & $4,6 \times 10^{2}$ & $8,5 \times 10^{2}$ & $<10$ & $2.7 \times 10^{2}$ \\
8 & $2,5 \times 10^{2}$ & $4,1 \times 10^{2}$ & $<10$ & $5.7 \times 10^{2}$ \\
10 & $<10$ & $<10$ & $<10$ & $<10$ \\
12 & $<10$ & $<10$ & $<10$ & $<10$ \\
\hline
\end{tabular}

Hasil uji ALT kopi bubuk selama penyimpanan menunjukkan terjadinya perubahan cemaran mikroba baik pada kopi bubuk yang dikemas menggunakan kemasan ALP maupun kemasan PET. Secara umum terjadi penurunan cemaran ALT selama penyimpanan. Penurunan cemaran ALT ini disebabkan oleh beberapa faktor yaitu keterbatasan oksigen yang tersedia di dalam kemasan karena dalam kemasan dilakukan nitrogen flushing sehingga kandungan oksigen di dalam kemasan menjadi sangat rendah. ALT juga disebut sebagai aerobic plate count (APC) atau aerobic microbial count (AMC) artinya mikrobia ini membutuhkan oksigen bebas untuk pertumbuhanya. Kekurangan oksigen di dalam kemasan menyebabkan mikrobia ALT tidak dapat tumbuh bahkan menjadi mati. Faktor lainnya adalah kadar air kopi bubuk yang sangat rendah $<2 \%$ menjadi penghambat untuk pertumbuhan mikrobia.

Selain itu kopi mengandung senyawa yang memiliki sifat anti-mikrobia sehingga dapat menurunkan pertumbuhan mikrobia (Fardiaz, 1995). Persidou (2015) merekomendasikan kopi sebagai bahan tambahan alami yang dapat memperpanjang dan menjaga stabilitas pangan seperti yoghurt, cookies, cake, atau biskuit. Runti et al. (2015) menyatakan bahwa ekstrak kopi menunjukkan efek bakteriostatik yang signifikan terhadap Staphylococcus aureus dan Staphylococcus epidermidis pada eksposur yang singkat serta menjadi bakterisidal setelah kontak yang lama. Jimenez-Zamora et al. (2015) menyatakan melanoidin kopi menunjukkan aktivitas antimikrobial yang dapat digunakan untuk menghindari bakteri pathogen pada produk pangan. Hasil uji juga menunjukkan bahwa penurunan ALT pada kopi bubuk yang dikemas dalam kemasan ALP lebih cepat dibandingkan dengan kopi bubuk yang dikemas dalam kemasan PET. Hal ini disebabkan karena kemasan ALP mempunyai sifat penghambatan terhadap udara. Menurut Pua et al. (2008) kemasan Aluminium foil dengan ketebalan 6 - $9 \mu \mathrm{m}$ lebih baik dibandingkan dengan kemasan berbahan polymer lainnya seperti PET.

Kapang adalah mikroba bersel tunggal berupa benang benang halus (hifa) yang berkembang biak dengan spora atau membelah diri, sedangkan khamir atau ragi adalah mikroba bersel tunggal berbentuk bulat-lonjong yang memperbanyak diri melalui tunas atau askospora berkembang dan tidak membentuk benang miselium. Kebanyakan kapang dan khamir bersifat aerob, dengan $\mathrm{pH} 2-9$, suhu $10-35^{\circ} \mathrm{C}$ dan kelembaban yang rendah, bahkan beberapa spesies dapat tumbuh pada aktivitas air 0,85 atau kurang. Beberapa strain menghasilkan mikotoksin utamanya okratoksin pada kopi. Kontaminasi kapang 
dan khamir pada pangan dapat menyebabkan kerusakan pada pangan yang ditandai dengan adanya noda dengan berbagai ukuran dan warna, bau apek, adanya miselium kapas putih atau aroma dan bau yang tidak normal. Standar Nasional Indonesia untuk kopi bubuk mensyaratkan batas maksimum cemaran kapang dan khamir pada kopi sebesar $1 \times 10^{4} \mathrm{koloni} / \mathrm{g}$.

Hasil uji pada Tabel 1 menunjukkan adanya cemaran kapang dan khamir pada kopi bubuk. Pada awal pengemasan angka kapang pada kopi bubuk 1,5 x 10 cfu/g. Cemaran kapang/khamir pada kopi dapat berasal dari bahan baku kopi biji dan metoda pengolahan kopi biji. Meskipun proses penyangraian kopi biasanya berlangsung pada suhu hingga $200^{\circ} \mathrm{C}$, tidak semua spora kapang dapat dihilangkan dan akan terbawa pada kopi bubuk yang dihasilkan. Hasil ini senada dengan penelitian Alvindia dan Acda (2010) dan Rahim et al. (2011) yang menemukan adanya kapang pada kopi yang berarti masih memenuhi persyaratan SNI untuk angka cemaran kapang/khamir.

Hasil penelitian juga menunjukkan terjadinya penurunan angka cemaran kapang/khamir selama penyimpanan. Penurunan angka cemaran kapang/ khamir pada kopi bubuk yang dikemas dalam kemasan ALP sudah terlihat pada bulan kedua, sedangkan pada kemasan PET penurunan angka cemaran kapang dimulai pada bulan ke 4 . Hal ini disebabkan karena kapang/khamir bersifat aerob artinya membutuhkan adanya oksigen untuk pertumbuhan. Kondisi kemasan kopi yang merupakan kondisi atmosfir dimodifikasi dengan penambahan gas nitrogen menyebabkan kandungan oksigen didalam kemasan menjadi hampir tidak ada sama sekali. Hal ini menyebabkan kapang/khamir yang ada pada kopi bubuk menjadi tidak dapat tumbuh. Hasil ini mirip dengan penelitian Ismail et al. (2013) yang menyatakan bahwa angka kapang dan khamir pada biji kopi liberika mengalami penurunan selama 8 bulan penyimpanan.

\section{KESIMPULAN}

Hasil penelitian menunjukkan bahwa jenis kemasan ALP dan PET mampu mempertahankan mutu kopi bubuk dari sisi mikrobiologi. Selama 12 bulan penyimpanan terjadi perubahan (penurunan) angka cemaran ALT dan angka cemaran kapang/kamir. Mutu kopi bubuk di dalam kemasan ALP dan PET yang disimpan selama 12 bulan masih memenuhi persyaratan mikrobiologi. Penentuan masa simpan kopi bubuk berdasarkan angka cemaran mikroba sebagai faktor pembatas tunggal akan memberikan informasi yang kurang akurat dan disarankan untuk dilanjutkan dengan penentuan menggunakan faktor pembatas lainya misalnya kadar air dan metode sensoris.

\section{UCAPAN TERIMA KASIH}

Penulis kontributor utama mengucapkan terima kasih kepada Dr. Ir. Sri Agustini, MSi atas bimbingan, arahan dalam pelaksanaan penelitian dan penulisan naskah KTI ini. Penulis juga mengucapkan terima kasih Kepala Balai Riset dan standardisasi Industri Palembang dan PD. Sahang Mas yang telah memfasilitasi penelitian ini.

\section{DAFTAR PUSTAKA}

Abdel-Bary, E.M.(2003). Handbookof Plastic Films. Shrewsbury Shropshire, UK: Rapra Technology LTD. pp 253.

Alvindia, D.G. and Acda, M.A. (2010). Mycoflora of coffee beans in the Philippines. Journal International Society for Southeast Asian Agricultural Sciences (ISSAAS), 16(2): $116-125$

AOAC.2009. Association of Official Analytic Chemist. Official Methods of Analysis of AOAC International (16 th Ed) Gaithersburg MD, USA: AOAC International.

Badan Standardisasi Nasional (2004). Kopi Bubuk. SNI 3542-2004. Jakarta.

Buffo, R.A dan Cardelli-Freire, C. (2004). Coffee Flavour: An Overview. Journal 
Sri Agustini, Penentuan Masa Simpan Kopi Bubuk Dalam Kemasan Aluminium Laminated

Oktavia Andayani Polyetilen (ALP) dan Poly Etilen Ptalat

of Flavour and Fragrance, 19(2):99104.

Cardelli, C and Labuza, T.P (2001). Application of Webull Hazard Analysis to the determination of the Shelf Life of Roasted and ground Coffee. Lebensminttel Wissenschaftund Technologies, 34:273-278.

Correa, P.C., de Oliveira, G.H.H., dan de Oliveira, A.P.L.R. (2016). Preservation of Roasted anf Ground Coffee during Storage. Part1: Moisture Content and Repose Angle. R.Bras. Eng. Agric. Ambiental 20(6):581-587.

Fardiaz, S (1995). Antimicrobial Activity of Coffee (Coffea robusta) Extract. ASEAN Food Journal, 10 (3) :103-106.

Herawati, H. (2008). Penentuan Masa Simpan Pada Produk Pangan. Jurnal Litbang Pertanian, 27(4):124-130.

International Coffee Organization. 2017. World Coffee Consumption. Available on line : http://www.ico.org/price/new consumption table.pdf (accessed on May 2019).

Hui, Y. (2006). Handbook of Food Science, Technology and Engineering. P. 102106. Boca Raton, Florida, USA: CRC Press.

Ismail, I., Anuar, M. S. and Shamsudin, R. (2013). Effect on the physicochemical properties of liberica green coffee beans under ambient storage. International Food Research Journal 20(1): 255-264

Jimenez-Zamora, A., Pastoriza, S., and

Rufian-Henares, J.A. (2015).

Revalorization of coffee by-products.

Prebiotic, antimicrobial and antioxidant properties. LWT - Food Science and Technology 61:12-18.

Kreuml, M.T.L, Majchrzak, D, Ploederl, B and Koenig, J. (2013). Changes in sensory quality characteristics of coffee during storage. Food Science \& Nutrition 1(4):267-272.

Mars, K dan Bagusu, B. (2007). Food Packaging Roles, Materials and Environmental Issues. Journal of FoodScience 72(3):R39-R55.

Mc.Gee, H. (2004). On Food and Cooking. Scribner Publisher New York, NY pp 441-448.

Persidou, T.A (2015). Microflora and antimicrobial activity of coffee.

Pua, C. K., Sheikh, Abd., Hamid. N., Tan, C. P., Mirhosseini, H., Abd., Rahman R. and Rusul, G. 2008. Storage stability of jackfruit (Artocarpus heterophyllus) powder packaged in aluminium laminated polyethylene and metallized co-extruded biaxially oriented polypropylene during storage. Journal of Food Engineering 89(4): 419-428.

Rahim, S.H.A., Ayob, M.K. and Ramli, N. (2011). Fungal contamination of commercial coffee powder. International Seminar on The Current Research Progress in Sciences and Technology (ISSTECH 2011).

Ross, C.F., Pecka, K., dan Weller. K. (2006). Effect of Storage Condition on the Sensory Quality of Ground Arabica Coffee. Journal of Food Quality 29 : 596-606.

Runti, G., Pacor, S., Colomban, S., Gennaro, R., Novarini, L dan Scocchi, M. (2015). Arabica coffee extract shows antibacterial activity against Staphylococcus epidermidis and Enterococcus faecalis and low toxicity towards a human cell line. LWT - Food Science and Technology, 62 (1): 108114.

Sudibyo, A., Hutajulu, T.F., dan Setyadjit. (2010). Pendugaan Masa Simpan Produk Kopi Instan Menggunakan Study Penyimpanan yang diakselerasi dengan Model Kinetika Arrhenius. Warta IHP, 27(1):12-24.

Vila, M.A., Andueza, S., De Pena, M., dan Cid, C. (2005). Fatty acid evolution during the storage of ground, roasted coffees. J.Am. Oil.Chem.Soc.82:639646.

Yulia, M dan Suhandy. D. (2018). Identification of fresh and expired ground roasted robusta coffee using UV-visible spectroscopy and chemometrics. MATEC Web of Conferences 197, 09003. doi.org/10.1051/matecconf/201819709 003 